\title{
Assessing the Toxic Levels in Parenting Behavior and Coping Strategies Implemented During the COVID-19 Pandemic
}

\author{
Hardiyanti Pratiwi ${ }^{1}$ \\ Universitas Islam Negeri Antasari Banjarmasin ${ }^{1,2,3,4,5}$ \\ Ikta Yarliani \\ Murniyanti Ismail \\ Rizki Noor Haida \\ Noer Asmayati
}

DOI: https://doi.org/10.21009/JPUD.142.03

Accepted: August $15^{\text {th }}$ 2020.Approved: September $4^{\text {th }} 2020$. Published: $30^{\text {th }}$ November 2020

\begin{abstract}
The COVID-19 pandemics have caused a lot of stressors for parents. Apart from doing daily activities, parents also have to take care of their children and accompany them to study. The number of stressors can lead to toxic behavior in parenting. This study aims to measure the level of toxicity in parenting behavior and coping strategies adopted by parents. This study uses quantitative descriptive methods to measure toxic levels in parenting behavior during the COVID-19 pandemic. A total of 568 parents from Banjarmasin and Yogyakarta participated in this study. The survey results show that several factors can trigger parenting stress during the COVID-19 pandemic, namely worsening economic conditions, delinquent children, excessive anxiety, accumulated daily hassles, growing family demands, and disputes with spouses. However, some of these stressors do not lead to toxic parenting. The results showed that $97.79 \%$ of respondents from Banjarmasin and 95.29\% from Yogyakarta showed a low toxic level. The remaining $2.21 \%$ of respondents in Banjarmasin and $4.71 \%$ of respondents in Yogyakarta indicated a moderate toxic level. Coping strategies are crucial for neutralizing stress. There are several strategies applied, namely trying to consider a problem is God's test, and there is a positive side to every problem; trying to address the source of stress and solving it; Withdrawing and finding individual time; looking for social support from the family and others; crying and releasing it by doing favorite things and capitulate and get back the problem. This Research is expected to be a reference for parents in choosing coping strategies to manage the stress they feel in parenting during the pandemic.
\end{abstract}

Keywords: Toxic parenting; stress trigger, coping strategy; COVID-19

\footnotetext{
${ }^{1}$ Corresponding Author:

Hardiyanti Pratiwi

Prodi PIAUD Fakultas Tarbiyah \& Keguruan

UIN Antasari Banjarmasin

Email: diyankonayuki@gmail.com
} 


\section{INTRODUCTION}

Parenting is a process of care that is applied by parents throughout the child's development. Care includes physical, emotional, and social aspects. Bodily care is related to protection against injury, cleanliness, provision of clothing, and food. Emotional care includes parental behavior and attitudes that show a sense of security and autonomy for children, provide opportunities for children to take decisions, and the capacity of parents to stimulate children's social care. So, parents are the primary reference for children, and therefore, they must set appropriate emotional and social attitudes in order to ensure healthy child development (Branco \& Linhares, 2018).

Many factors influence the ability of parents to care for their children. Belsky's (2005) model suggests three factors that influence parenting skills, namely individual parent factors, individual child factors, and environmental factors. Parental factors such as personality symptoms and psychopathology; individual child factors such as temperament, developmental delay and disability; and environmental factors, such as social context, social support, parental relationships, parental professions, as well as ancestral pasts. These factors can have an impact on the child's development directly or indirectly. There is much research that reveals that authoritative positive parenting and harmonious relationships built by parents with their children are very beneficial and influential for children in dealing with and managing the stress they will face in each phase of development (Badanes et al., 2012; Mortensen \& Barnet, 2020).

According to Shonkoff, stress that can be experienced by young children classified into three types (Jack P. Shonkoff \& Bales, 2011; Jack P. Shonkoff \& Levitt, 2010; Siegel et al., 2012). The first type is positive stress, which is a psychological state with a short duration and mild to moderate intensity. Children can cope with positive stress with adequate help and support from their parents. Positive stress experiences are widespread during childhood, such as fear of immunization and anxiety when first entering school. According to Shonkoff (J. P. Shonkoff et al., 2012) when children have a stable environment with protective and supportive relationships, the experience of positive stress can be a good challenge for children's growth and development. This challenge is an opportunity for adaptive learning to deal with negative experiences.

The second type is tolerable stress, associated with exposure to atypical experiences that present a higher level of difficulty or threat to individuals (J. P. Shonkoff et al., 2012; Jack P. Shonkoff \& Bales, 2011; Jack P. Shonkoff \& Levitt, 2010) for example, death of family members, illness severe, natural disasters, or even acts of crime. However, if children have a protective environment that supports them to cope, psychological risks in the short or long term can be moderated and reduced. When dealing with tolerable stress, parents must express child protection through relationships that are full of adaptive responses (J. P. Shonkoff et al., 2012)

Toxic stress is the third type of stress that children may experience. This kind of stress is the most dangerous event for child development, with negative consequences in several dimensions of life at the short, medium, and long-term levels. Toxic stress is characterized by frequent and robust reactivity to sources of stress stimulation (Jack P. Shonkoff \& Levitt, 2010; Siegel et al., 2012). Also, toxic stress is more dangerous because there is no support and protection from parents (J.P Shonkoff, 2012). Risk factors analyzed by the Adverse Childhood Experiences Study (Gilbert et al., 2015) mention several forms of stressors for this type of stress, such as child abuse or neglect, abuse of illegal substances by parents, and depression experienced by parents (Jack P Shonkoff, 2010; Jack P Shonkoff \& Fisher, 2013). This statement is in line with what was revealed by (National Scientific Council on the Developing Child, 2007) that toxic stress was an adverse childhood experience, caused by abuse, neglect and household dysfunction, which places children at risk of continued stress response activation without protection.

Toxic stress affects children's brain architecture and increases the risk of developing poor physical, behavioral, social-emotional, and cognitive health (J. P. Shonkoff et al., 2012). Toxic stress also interferes with the development of the nervous system, including the growth of parts of the brain associated with planning, problem-solving, and self-regulation (Felitti et al., 1998; Juster et al., 2010). This stress can affect a child's cognitive, behavior, and physical health disorders (Bethell et al., 2014). Toxic stress also causes various chronic diseases when the child is growing 
up, including heart disease, substance abuse, and depression (Braveman, 2009; Pediatrics, 2018). Families can be a substantial buffer to protect children from this toxic stress. Research shows that consistent and attentive communication, positive and responsive parenting can protect children from health hazards due to stress (National Academies of Sciences, Engineering, 2016).

Children who live in a bad family environment can show abnormal development. Children affected by toxic stress show higher levels of cortisol (a hormone that regulates stress) than other children who live in a healthy environment (Slopen et al., 2014). Cortisol is related to specific areas of the central nervous system that are responsible for regulating memory, learning, emotions, and the immunological system (Jack P Shonkoff et al., 2012). This finding shows that chronic illness can arise if children are often exposed to conditions that trigger stress. On the other hand, parents also have a high possibility of suffering stress while they care for their children. Parenting stress is the experience of distress or discomfort that results from parental role demands (Deater-deckard, 1998). In general, parenting has the consequence of causing high levels of stress (Koeske \& Koeske, 1990), especially in the preschool period (Kuczynski \& Kochanska, 1990). Parents who see their children as depressed or overly demanding, and unable to develop positive interactions with children can increase stress levels (Ostberg \& Hagekull, 2000).

The stress felt by parents from interactions with their children also depends on the psychological well-being of parents. Many studies have examined the factors that trigger this distress, including depression, lack of social support, marital disputes, and excessive anxiety (Davis \& Carter, 2008; Ekas \& Whitman, 2010). This kind of stress is possible emerged from many sources, including children, parents, and environmental characteristics (Abidin, 1990; Mash \& Johnston, 1990). The spread of COVID-19 and the enactment of WSFH can also be a factor in increasing stress on parents. This condition raises many factors simultaneously; excessive anxiety, increasingly difficult economic conditions, many children's tasks that must be handled by parents in addition to their tasks, and the lack of social support from various parties due to social distancing. The rush of stress-triggering factors at the same time can reduce the psychological condition of parents so that they fall into toxic parenting behaviors.

Researchers found several previous studies on parenting stress, including: The Relationships Between Parenting Stress, Parenting Behavior and Preschoolers' Social Competence and Behavior Problems in the Classroom (Anthony et al., 2005), the results showed that Parenting stress was most strongly related to children's social competence. Then another study entitled Toxic Parenting Adversely Correlates To Students 'Academic Performance In Secondary Schools In Uasin Gishu County, Kenya (K. et al., 2020), This study concluded that toxic parenting adversely correlated to students' academic performance. Researchers have not found an article that discusses toxic behavior carried out by parents when under stress in raising early childhood. The purpose of this study was to measure the level of toxicity in parenting behavior by parents towards their children who were still at an early age during the COVID-19 pandemic, as well as to determine the coping strategies applied by parents in dealing with stress in caring for their children during the COVID19 pandemic.

\section{THEORITICAL STUDY}

\subsection{Toxic Parenting}

Toxic parents are those who demonstrate life and interaction styles that damage children's ability to form healthy connections with family members, friends, and partners. Every parent does tend to make mistakes. In the frequency and intensity of specific interactions, those mistakes can harm the child. These impacts can last in the long term, implicating self-esteem, friendship, and a warm relationship between children and their parents (Mikulincer et al., 2010).

Embedding poisonous words in parenting looks rather harsh. However, upon closer examination, this analogy is precisely correct. Toxic substances are complex and not always dangerous if used under certain conditions and doses. Likewise, poisonous parenting can be good at first but applied to the wrong situations and excessive doses that damage the child. For example, when 
parents set strict regulations for their children, it might have reasonable goals. However, it can cause a backlash from children or even make them insecure.

Another example, parents show affection for children as a way to express attention, warmth, and love. However, excessive love can make children feel uncomfortable and can even step into the realm of sexual abuse. Toxicity varies according to many factors: level of exposure, repetition of exposure, preparation, purpose, and individual sensitivity of the person absorbing the substance. Parents and their systematic style of interacting with children can be drugs or poisons for interpersonal relationships (Mikulincer et al., 2010). Certain behaviors such as competition, ridicule, humor, control, and punishment can all have healthy or dangerous effects depending on the intensity, expression, how many times they occur, the context in which they are expressed, and the psychological and interpersonal needs and sensitivity of the child.

Dunham and Dermer (2011) Describe three types of toxic parents, namely: Contest parents, dismissive parents, and contemptuous parents who are insulting. Contest parents try to make children as they wish. Through the successes of the infant, this form of parent receives pseudo-selfesteem. Parents encourage children to accept their wishes as child goals. The dismissive parent is not connected with children in the way intended. Parents may not be physically, emotionally, or financially available. Dismissive Parents may be in the house every day, but they are busy with their own lives and not involved in the children's lives. They may provide basic needs but without a warm emotional connection.

Contemptuous parents are judges of the needs, desires, and dreams of their children. They depend on disparaging, criticizing, cursing, and blackmailing their children emotionally. Humiliation always causes disgust and effective in damaging relationships (Gottman \& Silver, 1999). The parent expressed the insult through sarcasm, cynicism, summons, rolling eyes, sneering, mocking, and hostile humor. If parents become toxic parents, then the child will not have a backrest in dealing with stress. Even, toxic parents can be a source of toxic stress in children. This study intends to measure the toxic level of parenting behavior that is applied by parents during the COVID-19 pandemic. This research will also reveal the stress triggering factors experienced by parents and the coping strategies they employ.

\subsection{Parenting Stress}

In the article (Crnic et al., 2005) mentions parenting stress is closely related to negative attitudes in parenting, parental well-being, and negative parenting behavior. The higher parenting stress is also dominated by authoritarian parenting styles, in the negative interaction patterns between children and parents, and the low involvement of parents in parenting. In addition, the hassles of day-to-day parenting also contributes to parenting stress. Stress triggers for parents are also due to the lack of knowledge about parenting, lack of perceived competence, and lack of emotional support such as assistance in caring and daily work from spouses, other family members, as well as assistance from closest people (friends). The arrival of a new baby is a joy to a family, but being a new parent also leads to new jobs and demands for parenting. These new demands can be a stressor for young mothers or parents who have no previous experience in parenting (Deater-deckard, 1998). Stress in parenting occurs because of the obligation to be a parent (Anthony et al., 2005).

\subsection{Coping Strategy}

Coping strategy is a disposition variable that refers to individual characteristics that are relatively stable. The results of research conducted on various groups show that emotionally oriented coping strategies (such as grumbling, self-blame) positively correlated with health problems such as depression and anxiety. Whereas problem-oriented coping (an active approach to be problemsolving) negatively correlated with these conditions (Cohan et al., 2006). In a study conducted by Rodenburg et al., (2007), social support complemented family cohesion and coping behavior that focused on finding the source of a problem and solving it contributed to lower levels of parenting stress. However, in this study, coping strategies by trying to understand the source of stress problems and solve them only rank second while looking for social support ranks fourth. The majority 
of respondents prefer coping strategies based on religious values, which are trying to understand that the problem is a test of God and that there is a positive side to every problem.

\section{METHOD}

This study uses a quantitative method with a descriptive form. Respondents came from two different cities: Banjarmasin and Yogyakarta. The researcher chooses Banjarmasin city because it is known as a religious city. This city is full of the number of mosques and ta'lim assemblies. Many assemblies attended by tens of thousands of people every day. Yogyakarta city becomes the second place for research because this city was famed as a learning city. In this city, we can find many high-quality universities. Yogyakarta absorbs many people to study there. This educative climate positively affects the life patterns of the Yogyakarta citizens. The research instrument was a closed questionnaire with a Likert scale and an open questionnaire. Data collection techniques in the form of distributing questionnaires. Data were analyzed using SPSS.

\subsection{Participant}

The population of PAUD students in Yogyakarta city is 13,559 people, while in Banjarmasin, there are 15,912 people. The questionnaire distributed and filled out by the parents of each child selected to be the sample. Samples were taken by referring to the Isaac Michael table with a significance level of $10 \%$ so that 266 children from Yogyakarta and 267 children from Banjarmasin. The questionnaire to measure the toxic level of parenting behavior developed from the toxic parent indicator mentioned at https://id.theasianparent.com/toxic-parents. These indicators are selfish, lacking empathy; emotionally reactive; lack of respect for children; excessive control; criticizing and blaming all mistakes on children; demanding something that cannot be done by children to then underestimate and compare it with others, and bringing up what he has done for the child causing guilt.

\subsection{Instruments Penelitian}

Table 1. Indicator and item in questionnaire

\begin{tabular}{|c|c|c|c|c|}
\hline No & Indicator & Item & rxy & Ket \\
\hline \multirow[t]{2}{*}{1} & Selfish, lacking & I feel that children always interfere when I want to relax & $.424^{* *}$ & Valid \\
\hline & & $\begin{array}{l}\text { If a child falls down and cries, I will not calm him } \\
\text { down, even I will scold him or tell him to cry to his } \\
\text { heart's content }\end{array}$ & $.525^{* *}$ & Valid \\
\hline \multirow[t]{2}{*}{2} & $\begin{array}{l}\text { Emotionally reac- } \\
\text { tive }\end{array}$ & $\begin{array}{l}\text { I shouted if the child did not immediately respond when } \\
\text { called }\end{array}$ & $.378^{* *}$ & Valid \\
\hline & & $\begin{array}{l}\text { I immediately punish a child with physical punishment } \\
\text { if he troubles me (hitting, tweaking or pinching, etc.) }\end{array}$ & $.541^{* *}$ & Valid \\
\hline \multirow[t]{2}{*}{3} & $\begin{array}{l}\text { Control children } \\
\text { tightly }\end{array}$ & $\begin{array}{l}\text { I get annoyed if the child does something that is not ex- } \\
\text { actly what I want }\end{array}$ & $.463^{* *}$ & Valid \\
\hline & & $\begin{array}{l}\text { I will not fulfill the wishes of the child if he does not do } \\
\text { what I command }\end{array}$ & $.484^{* *}$ & Valid \\
\hline \multirow[t]{3}{*}{4} & $\begin{array}{l}\text { Lack of apprecia- } \\
\text { tion }\end{array}$ & $\begin{array}{l}\text { If a child wants to help when I do something, I will re- } \\
\text { ject it because it will only slow down my work }\end{array}$ & $.440^{* *}$ & Valid \\
\hline & & $\begin{array}{l}\text { I pout children when they fail to do what they want or } \\
\text { achieve what they expect }\end{array}$ & $.410^{* *}$ & Valid \\
\hline & & I am angry if the child says my opinion is wrong & $.526^{* *}$ & Valid \\
\hline \multirow[t]{2}{*}{5} & $\begin{array}{l}\text { Blame the child } \\
\text { excessively }\end{array}$ & $\begin{array}{l}\text { I felt that I could not do anything if the child was around } \\
\text { me }\end{array}$ & $.624^{* *}$ & Valid \\
\hline & & $\begin{array}{l}\text { Children often cause me to argue with my partner (hus- } \\
\text { band / wife) }\end{array}$ & $.444^{* *}$ & Valid \\
\hline
\end{tabular}




\begin{tabular}{lllll}
\hline & & $\begin{array}{l}\text { My economic condition is a mess because many chil- } \\
\text { dren will }\end{array}$ & $.330^{*}$ & Valid \\
6 & $\begin{array}{l}\text { Disparaging and } \\
\text { comparing children }\end{array}$ & $\begin{array}{l}\text { If it's a bad boy, I call him a nickname he doesn't like } \\
\text { (like bad boys, whiny kids, spoiled kids, etc.) } \\
\text { I told my child that he was not as good as his brother } \\
\text { (brother / sister) or other family }\end{array}$ & $.535^{* *}$ & Valid \\
& $\begin{array}{l}\text { Bring up what has } \\
\text { been done for the } \\
\text { child }\end{array}$ & $\begin{array}{l}\text { I warned the child not to be naughty because I had spent } \\
\text { a lot money on him }\end{array}$ & $.388^{* *}$ & Valid \\
& $\begin{array}{lll}\text { I warn the child to appreciate the effort I put into raising } \\
\text { him, so he has to carry out my orders }\end{array}$ & $.441^{* *}$ & Valid \\
\hline
\end{tabular}

The result categorization of the questionnaire guided by the provisions proposed by Arikunto, (1998), namely:

Table 2. Categorization of Questionnaire Results to classify toxic level

\begin{tabular}{lll}
\hline No & Category & Range \\
\hline 1 & Very Good & $76-100$ \\
2 & Good & $50-75$ \\
3 & Not Good & $40-55$ \\
4 & Very Not Good & $<40$ \\
\hline
\end{tabular}

\section{RESULT AND DISCUSSION}

\subsection{Result}

\subsubsection{Respondent Demographics Data}

Respondents who participated in this survey were 568 people, exceeding the specified number of samples. Two hundred ninety-seven parents come from Yogyakarta and 271 parents residing in Banjarmasin (see table 3).

Table 3. Demographic Data of Respondents

\begin{tabular}{clc}
\hline No & Respondent & Percentage \\
\hline 1 & Gender & \\
& Woman / mother & 95.4 \\
& Male / father & 4.6 \\
2 & Age & 33.6 \\
& 21-30 years & 51.1 \\
& 31-40 years & 15.3 \\
& 41-50 years & \\
3 & Profession & 50 \\
& housewife & 17.3 \\
& Honorary staff & 7.6 \\
& Government employees & 14.4 \\
& General employees & 10.7 \\
4 & Entrepreneur & \\
4 & Last Education & 6.7 \\
& Graduate program & 34.2 \\
& Undergraduate program & 7 \\
\hline
\end{tabular}




\begin{tabular}{|c|c|c|}
\hline & Senior High School & 41 \\
\hline & Junior High School & 9 \\
\hline & Elementary School & 2.1 \\
\hline \multirow[t]{5}{*}{5} & Number of children & \\
\hline & 1 & 26.4 \\
\hline & 2 & 46.7 \\
\hline & 3 & 20.6 \\
\hline & $>3$ & 6.3 \\
\hline \multirow[t]{7}{*}{6} & Monthly family cumulative income & \\
\hline & $<\operatorname{Rp} 500.000$ & 8.6 \\
\hline & Rp 500.000 - Rp 1.000 .000 & 14.8 \\
\hline & $>$ Rp $1.000 .000-$ Rp. 2.000 .000 & 16.5 \\
\hline & $>$ Rp 2.000.000 - Rp. 3.000 .000 & 18.1 \\
\hline & $>$ Rp $3.000 .000-$ Rp. 4.000 .000 & 13.7 \\
\hline & $>$ Rp.4.000.000 & 28.2 \\
\hline
\end{tabular}

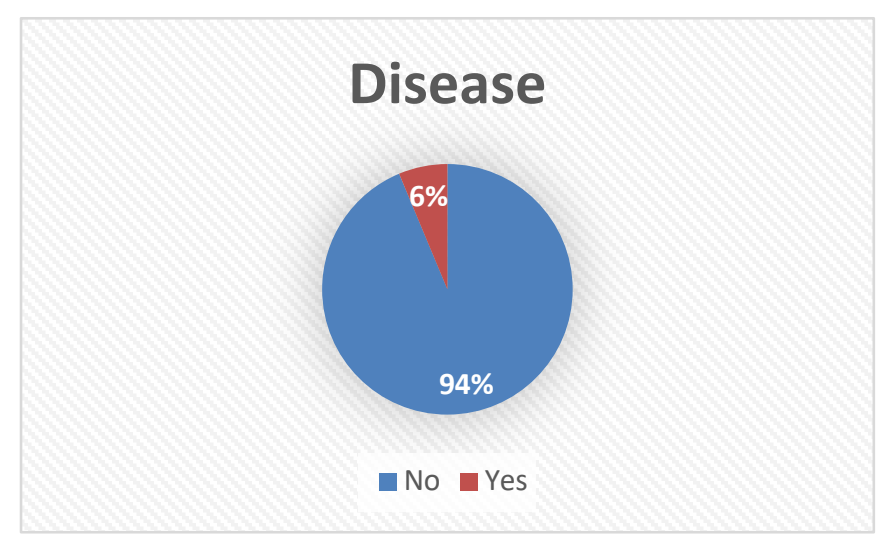

Figure 1. Disease

Figure 1, as many as $93.7 \%$ of respondents said they did not have a congenital disease that could make their emotions unstable. While the remaining $6.3 \%$ said they have a condition that can affect emotional stability. The disorders include hypertension, internal diseases, acute gastritis, diabetes, cholesterol, and postoperative trauma.

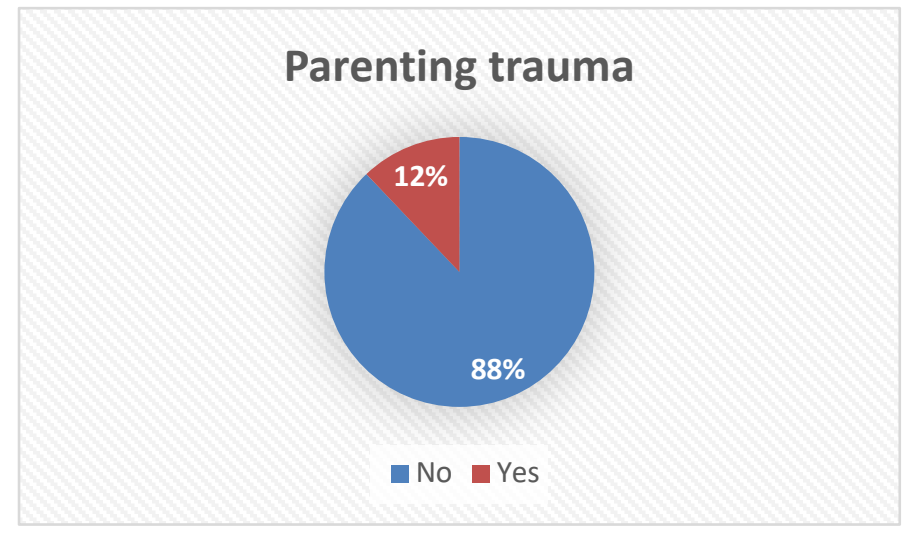

Figure 2. Parenting Trauma

Figure 2 show, as many as $87.9 \%$ of respondents stated that they had never experienced poor care by their parents before. While the rest, $12.1 \%$ said they had experienced trauma due to the abusive attitude done by parents. 


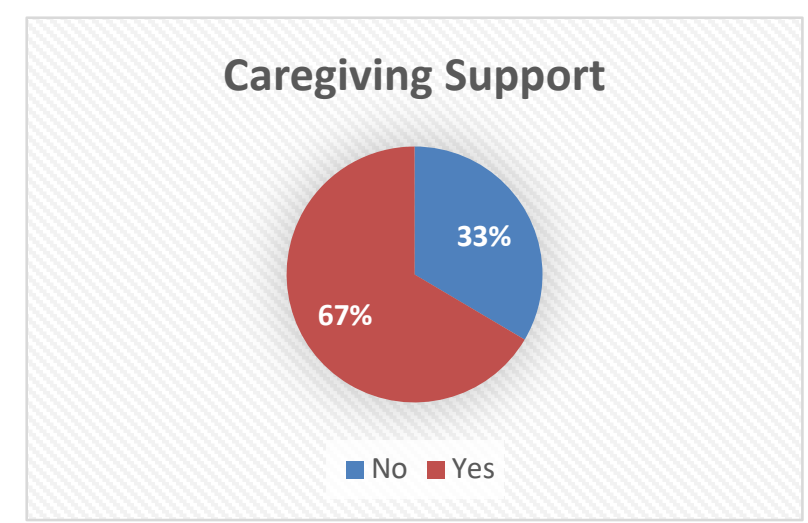

Figure 3. Caregiving Support

As many as $33.5 \%$ of respondents in figure 3, said that they take care of their children without the support of other parties. The remaining $66.5 \%$ stated that they received nurturing support from various parties, especially their husbands. Besides, they also received support from siblings, parents, grandmothers, teachers, motivators, parenting sharing groups, and books.

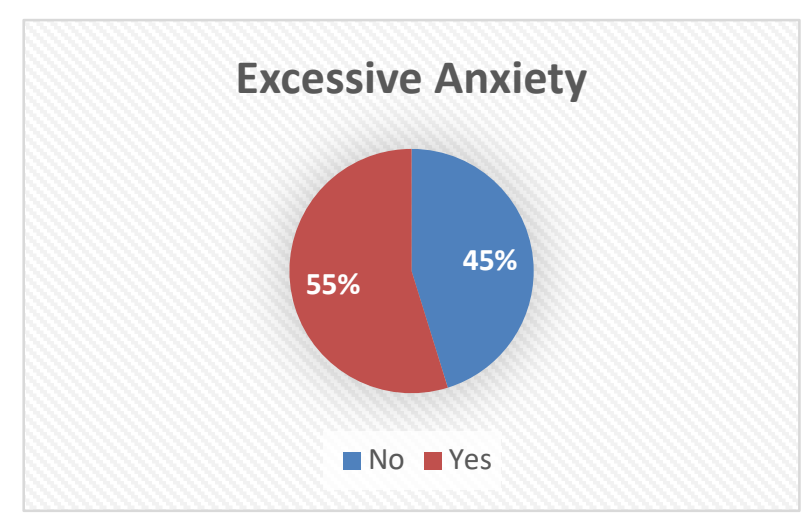

Figure 4. Excessive Anxiety

When asked about the anxiety they felt during the co-19 pandemic, $54.8 \%$ of respondents said they felt more anxious than before. While the rest, $45.2 \%$ of respondents stated that there was no significant increase in anxiety due to the spread of the coronavirus in their area (see figure 4).

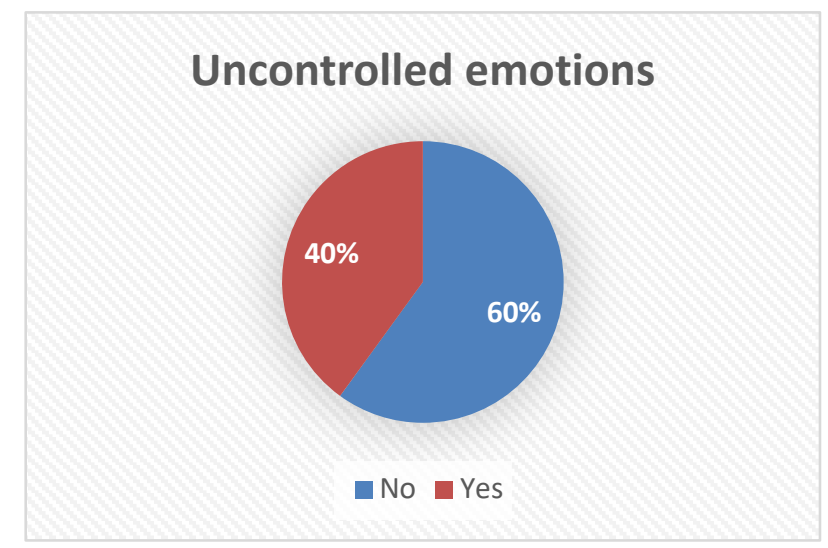

Figure 5. Uncontrolled Emotion

During WSFH, as many as $40 \%$ (see figure 5) of respondents felt angrier and had difficulty controlling their emotions compared to the previous time. The other $60 \%$ of respondents did not feel difficulty in controlling emotions in their current state. 


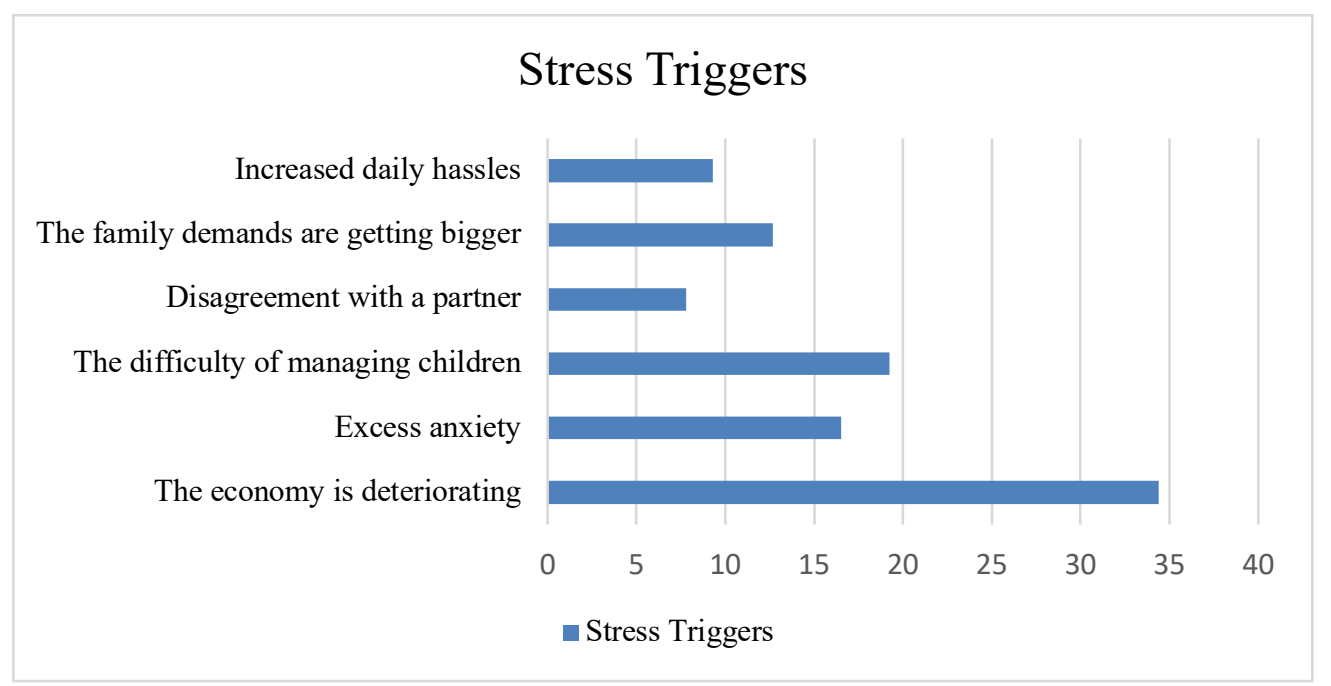

Figure 6. Stress Trigger Chart

There were 805 responses regarding stress triggers felt by parents during this co- 19 pandemic. As many as $34.41 \%$ or 277 responses stated that a worsening economy could trigger stress more quickly. Then $19.25 \%$ or 155 responses stated that children who are challenging to manage when parents work at home also create stress. Followed by excessive anxiety and fear infected by COVID-19 expressed can make parents stressed by 16.53 or 133 responses. Then the growing family demands when the pandemic COVID-19 is also considered by $12.67 \%$ or 102 responses as stressors. Increased daily hassles, including taking care of homework, completing office tasks, and accompanying children to learn, also adds to the stress burden of parents. A total of $9.32 \%$ or 75 respondents said this. Finally, $7.82 \%$ or 63 responses stated disagreements with partners when arranging some things during the coronavirus spread were also considered to trigger stress for parents (see figure 6).

It is widely recognized that parenting might be stressful. Parenting stress defined as an adverse psychological reaction to parental demands (Deater-deckard, 1998). However, this reaction is multi-sided and depends on several factors, including parent's psychological, health, relationship with their child, source of support, and their own experience as a parent (Anthony et al., 2005). Therefore, parents will differ in the amount of stress they experience, although most parents will still experience stress at some point. Research shows that increased parental stress can harm parent-child relationships (Deckard \& Scarr, 1996). For example, stress can make parenting harder and be bound to the imposition of punishment, thus resulting in lower emotional development for children (Crnic et al., 2005).

Parents' own experiences of their childhood and the style of care received tend to be the primary determinant of the style of care they will apply to their children. Research has shown that the experience of ill-treatment received by parents when they become children tends to have a detrimental effect on subsequent caregiving abilities (Fitzgerald et al., 2005). For example, a strong correlation identified between mothers who experienced physical abuse during childhood and records of the abuse of their babies who were not yet 26 months old (Berlin et al., 2011). Mothers who experience childhood emotional distress reported to display less empathic responses to their babies who are six months old and have lower scores on parental self-efficacy (Caldwell et al., 2011).

\subsubsection{Description of Toxic Levels in Parenting behavior during the COVID-19 Pandemic Pe- riod}

All items in this questionnaire are unfavorable. Scoring uses a Likert scale. Options never get a value of 4 , sometimes get 3 , often get 2 , and always get the lowest value of 1 . The following is a statistical description table of the results of a questionnaire from two different cities: 
Table 4. Results of a questionnaire from two different cities

\begin{tabular}{|c|c|c|c|}
\hline \multicolumn{4}{|c|}{ Statistics } \\
\hline & & Banjarmasin & Yogyakarta \\
\hline \multirow[t]{2}{*}{$\mathrm{N}$} & Valid & 271 & 297 \\
\hline & Missing & 26 & 0 \\
\hline \multicolumn{2}{|c|}{ Mean } & 56.81 & 56.76 \\
\hline \multicolumn{2}{|c|}{ Median } & 57.00 & 57.00 \\
\hline \multicolumn{2}{|c|}{ Mode } & 60 & 56 \\
\hline \multicolumn{2}{|c|}{ Std. Deviation } & 3.880 & 4.158 \\
\hline \multicolumn{2}{|c|}{ Variance } & 15.057 & 17.286 \\
\hline \multicolumn{2}{|c|}{ Range } & 22 & 22 \\
\hline \multicolumn{2}{|c|}{ Minimum } & 42 & 42 \\
\hline \multicolumn{2}{|c|}{ Maximum } & 64 & 64 \\
\hline \multicolumn{2}{|c|}{ Sum } & 15396 & 16857 \\
\hline
\end{tabular}

From this table, the number of samples from Banjarmasin city is 271 people, and from Yogyakarta city is 297 people. The average value obtained by all respondents who live in Banjarmasin is 56.81, while respondents from Yogyakarta have an average value of 56.76. the minimum and maximum values obtained from these two different cities are identical, namely 42 and 64 . Similarly, the median value that gets the same points as 57.00. the mode results of individual questionnaire obtained by parents from Banjarmasin are 60, while parents in Yogyakarta get a value of 56. From this statistical table, there is no noticeable difference from the questionnaire results obtained in the two cities where the study conducted.

\subsubsection{Categorization of Toxic Levels in Parenting behavior during COVID-19 Pandemic Pe- riod}

This categorization follows the guidelines set by Arikunto (2010). Because all questionnaire questions are unfavorable, the categories reversed. The higher the score obtained by the respondent, the lower the toxic level applies. The result categorization of the questionnaire from the following table:

Table 5. Result categorization of the questionnaire

\begin{tabular}{rllll}
\hline No & Category & Range & Banjarmasin & Yogyakarta \\
\hline 1 & Low toxic level & $76-100$ & $265 / 97.79 \%$ & $283 / 95.29 \%$ \\
2 & Moderate toxic level & $50-75$ & $6 / 2.21 \%$ & $14 / 4.71 \%$ \\
3 & High toxic level & $40-55$ & - & - \\
4 & very high Toxic level & $<40$ & - & - \\
\hline
\end{tabular}

The following is the average value of each indicator

Table 5. The average value of each indicator

\begin{tabular}{llcc}
\hline No & Indicator & Banjarmasin & Yogyakarta \\
\hline 1 & Selfish, lacking empathy & 3.36 & 3.42 \\
2 & Emotionally reactive & 3.33 & 3.39 \\
3 & Control children tightly & 3.15 & 3.11 \\
4 & Lack of appreciation & 3.69 & 3.7 \\
5 & Blame the child excessively & 3.63 & 3.61 \\
6 & Disparaging and comparing children & 3.82 & 3.76 \\
7 & Bring up what has been done for the child & 3.72 & 3.7 \\
\hline
\end{tabular}

Parents from Banjarmasin and Yogyakarta both received the lowest scores on the third indicator. It concluded that the aspect of controlling children is an indicator that often causes toxic 
parenting. The highest value is in the sixth indicator. It concluded that the aspect of underestimating children and comparing them with other children is the unusual behavior performed by parents in parenting, both those who live in Banjarmasin and Yogyakarta.

\subsubsection{Coping Strategies to Prevent Toxic Parenting Behavior}

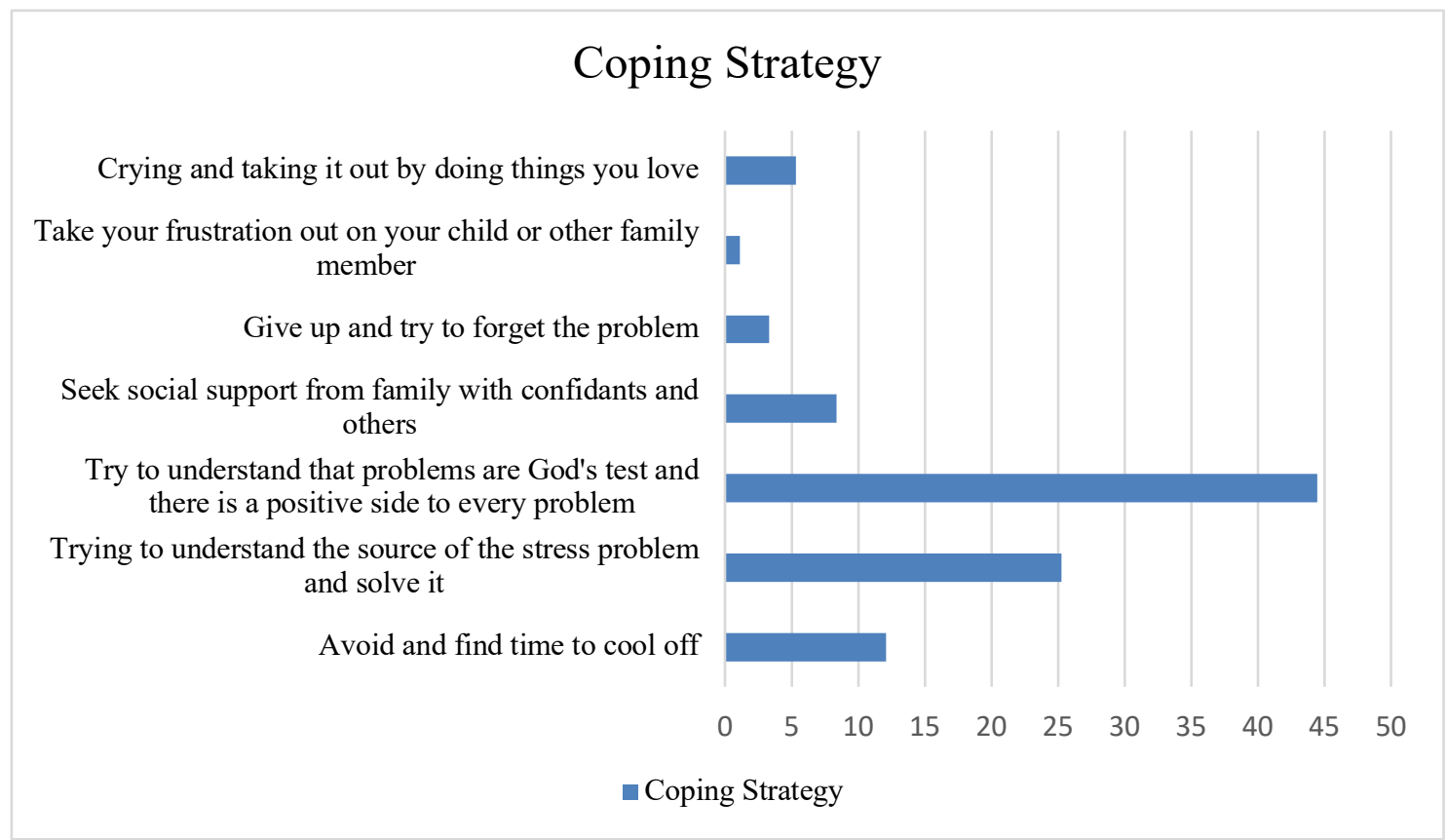

Figure 7. Coping Strategy

There are 787 responses regarding coping strategies applied by parents when they respond the parental stress. The most coping strategy practiced by parents is Trying to understand that the problem is God's test, and there is a positive side to every problem. This religious strategy is chosen by 350 responses or equivalent to $44.47 \%$. The second most preferred strategy is trying to understand the source of stress and solve it. There were 199 responses or $25.28 \%$ who chose this strategy. Avoiding and finding time to calm down is the third most chosen strategy by respondents. There were 95 responses, or $12.07 \%$ chose this strategy. Then as many as 66 responses or $8.38 \%$ chose the strategy of seeking social support from families with confide and the like when facing the stress of care.

Furthermore, as many as 42 responses or $5.33 \%$ chose to cry and vent by doing what they liked. There are 26 responses or 3.30 who chose to surrender and try to forget the problem when stressed caregiving. Finally, there are only nine responses or $1.14 \%$ that vent frustration to children or other family members when stressed. If classified from 787 responses, 341 responses came from parents who live in Banjarmasin and 424 responses from parents who live in Yogyakarta. There was one respondent who stated that if the parenting stress hit her, usually she would do something harming himself. Following is the percentage of coping strategies compared between the two cities where the research held:

Table 6. Percentage of Coping Strategies Compared Between the Two Cities Where the Research Held

\begin{tabular}{clll}
\hline No & Coping Strategies & $\begin{array}{l}\text { Banjarmasin } \\
\text { Percentage }\end{array}$ & $\begin{array}{l}\text { Yogyakarta } \\
\text { Percentage }\end{array}$ \\
\hline 1 & $\begin{array}{l}\text { Avoid and find time to calm down } \\
\text { Trying to understand the source of the stress problem } \\
\text { and solve it }\end{array}$ & 11.14 & 12.73 \\
& 27.56 & 24.06 \\
3 & $\begin{array}{l}\text { Trying to understand that the problem is God's test and } \\
\text { there is a positive side to every problem } \\
4\end{array} \quad$ Seek social support from family by vent etc. & 48.97 & 42.93 \\
\hline
\end{tabular}




\begin{tabular}{llll}
\hline 5 & Surrender and try to forget the problem & 2.06 & 3.77 \\
6 & Vent your frustration to the child or other family mem- & 0.58 & 1.42 \\
& bers & & \\
7 & Cry and vent it out by doing something you like & 4.11 & 5.18 \\
\hline
\end{tabular}

\subsection{Discussion}

In stressful parenting situations, parents make cognitive judgments about their situational control, which is the extent to which they are confident they can manage stress in the context of raising children. This assessment is the product of parental evaluation of the demands of the situation, as well as their coping resources, options, and ability to implement the required coping strategies (Lazarus, 1993). Parental resources defined as stress relief and parental coping practices defined as the way parents manage stress.

The conditions of respondents found in this study included diseases that could trigger stress, such as hypertension, internal disease, acute ulcers, diabetes, cholesterol and postoperative trauma. However, this percentage is only $6 \%$. Then there is the trauma of parenting during childhood due to rude attitudes carried out by parents. However, this percentage is only $12.1 \%$. Then parenting support, of which $33.5 \%$ of respondents stated that they cared for their own children without any support from other parties. There was excessive anxiety during the COVID-19 pandemic, which was $54.8 \%$. During WSFH, as many as $40 \%$ of respondents felt more irritable and had difficulty controlling their emotions compared to the previous time. These conditions can also trigger stress factors.

As for the stressors felt by parents in childcare during the COVID-19 pandemic, 34.41\% or 277 responses stated that a deteriorating economy can trigger stress more quickly. These stressors are the ones most expressed by respondents. During the COVID-19 Pandemic, large-scale social restrictions or lock downs were imposed, which caused several offices and shops to close. This certainly has an impact on the economy of the community, which must temporarily close their shops. There are also those who continue to sell, but there are fewer buyers. Then, there were some workers who were also laid off because the company made a reduction in employees. It turns out that this condition contributes to the stress of parents in caring for their children, as in the article (Crnic et al., 2005) mentioned one of the stressors is parental well-being.

As many as $19.25 \%$ or 155 responses (the second highest choice of respondents) stated that children who are difficult to manage when their parents work at home are also stressful. Children who learn from home become difficult to manage because they feel there is freedom at home, unlike at school. Parents who are accustomed to not being with their children during school hours are certainly surprised by this condition. Children and parents gather for 24 hours, parents are busy, and children are difficult to manage. This can occur due to the low involvement of parents in care during the pre-COVID 19 pandemics, as CRNC wrote that the low involvement of parents in care can be a trigger for stress in parenting.

Excess anxiety and fear of being infected with COVID-19 were stated to stress parents by $16.53 \%$ or 133 responses. Excess anxiety also occurs due to a lack of adequate understanding of something, such as COVID-19. At the beginning of its appearance, it was very surprising, with a million deadly viruses, causing parents to have excessive anxiety because they were afraid of being infected with the COVID-19 virus. $12.67 \%$ or 102 responses considered the increasing family demands during the COVID-19 pandemic as a trigger for stress. Especially during the lockdown period, people were too panicked, so they did panic buying, which is buying excess daily necessities for fear of leaving the house. Apart from that, there is also a need to buy internet data quotas because children and parents work online. Likewise, with the increasing demands of daily activities.

As many as $9.32 \%$ or 75 respondents stated that the Increasing daily hassles, including taking care of homework, completing office tasks and accompanying children to study also increase the stress burden on parents. This is related to the results of research which states that the hassles of 
daily parenting also contribute to parenting stress (Crnic et al., 2005). When parents work from home, and their children go to school from home, it means that the inconvenience of parents at home is increased by taking care of daily work coupled with the task of helping children learn from home. Of the several stressors, the level of toxic parenting is still at a low level, both for Banjarmasin and Yogyakarta. the love to control the child tightly is an indicator that often causes toxicity in care. The highest value is obtained in the sixth indicator on the aspect of underestimating children and comparing them with other children. This means that this behavior is rarely carried out by parents in a toxic upbringing style.

The attitude of controlling children is strictly seen from most respondents who want what the child does according to the wishes of the parents, it must be in accordance with what is instructed, so that when children do something that is not in accordance with the wishes of the parents, this can be an indicator of toxicity in parenting. The next indicator is that the parents do not want to fulfill the child's wishes if the child does not want to do what the parents tell them to do. This type of toxic parenting will harm the child psychologically. Physically and verbally, it doesn't look like a toxic form, but it attacks the child psychologically. In contrast to the type of toxicity that parents rarely due to their children, namely underestimating children and comparing them to other children. For example, calling a child with a call he doesn't like, such as a naughty child, a crybaby, a spoiled child. Apart from that, another indicator is telling the child that he is not as good as his sibling (brother / sister) or other family. This type of toxicity is verbal.

Coping strategy is a disposition variable that refers to individual characteristics that are relatively stable. The results of research conducted on various groups show that emotionally oriented coping strategies (such as grumbling, self-blame) positively correlated with health problems such as depression and anxiety. Whereas problem-oriented coping (an active approach to problemsolving) negatively correlated with these conditions (Cohan et al., 2006). In a study conducted by (Rodenburg et al., 2007), social support complemented family cohesion and coping behavior that focused on finding the source of a problem and solving it contributed to lower levels of parenting stress. However, in this study, coping strategies by trying to understand the source of stress problems and solve them only rank second while looking for social support ranks fourth. The majority of respondents prefer coping strategies based on religious values, which are trying to understand that the problem is a test of God and that there is a positive side to every problem.

This finding confirms the results of previous research, which states that in Indonesian culture, parental stress minimized by religious coping. Religion and spirituality have proven to contribute positively to the exact process of life in various ways, such as religion providing support to overcome the problem of stress, and religion can make mothers and families grateful and interpret the presence of children with autism spectrum disorders positively (Daulay, 2018). Research held by (Corrigan et al., 2003) also found that religious involvement has a positive correlation with psychological well-being..

\section{CONCLUSION}

Respondents stated that the spread of COVID-19 caused several stressors, namely deteriorating economic conditions, difficulty controlling children, excessive anxiety over the spread of the virus, growing family demands, increased daily hassles due to having to take care of homework, offices and child chores, then disagreement with a partner. However, the stress experienced by parents in their parenting behavior does not lead to them becoming toxic parents. The results showed that $97.79 \%$ of respondents from Banjarmasin and 95.29\% from Yogyakarta showed a low toxic level. The remaining $2.21 \%$ of respondents in Banjarmasin and $4.71 \%$ of respondents in Yogyakarta indicated a moderate toxic level. There were no respondents who had high toxic levels. Coping strategies applied by parents influence the low level of toxic parenting during the spread of the co-19 pandemic. The majority of respondents implement religious coping strategies by instilling awareness that the problem is part of God's plan, which always has a positive side, then followed by problem-solving coping strategies. Respondents admitted that they faced more stressors during the COVID-19 pandemic, but the level of toxicity in the majority of caregiving was still low, both in Banjarmasin and Yogyakarta. This is because parents can manage stress with religious coping techniques. This coping technique is emotional. Although this technique is 
effective, it is defensive in nature. Parents are still expected to develop coping techniques that focus on problem solving

\section{REFERENCES}

Abidin, R. R. (1990). Parenting Stress Index (PSI) manual. Psychological Assessment Resources, Inc.

Anthony, L. G., Anthony, B. J., Glanville, D. N., Naiman, D. Q., Waanders, C., \& Shaffer, S. (2005). The Relationships Between Parenting Stress, Parenting Behaviour and Preschoolers' Social Competence and Behaviour Problems in the Classroom. Infant and Child Development, 14(2), 133-154. https://doi.org/10.1002/icd

Arikunto, S. (2010). Prosedur Penelitian Suatu Pendekatan Praktik. Asdi Mahasatya.

Badanes, L. S., Dmitrieva, J., \& Watamura, S. E. (2012). Understanding cortisol reactivity across the day at child care: The potential buffering role of secure attachments to caregivers. Early Childhood Research Quarterly, 27(1), 156-165. https://doi.org/10.1016/j.ecresq.2011.05.005

Belsky, J. (2005). Social-contextual determinants of parenting. In Encyclopaedia on early childhood development.

Berlin, L. ., Appleyard, K., \& Dodge, K. . (2011). Intergenerational continuity in child maltreatment: mediating mechanisms and implications for prevention. Child Development, 82, 162-176. https://doi.org/10.1111/j.14678624.2010.01547.x

Bethell, C. D., Newacheck, P., Hawes, E., \& Halfon, N. (2014). Adverse childhood experiences: assessing the impact on health and school engagement and the mitigating role of resilience. Health Affairs, 33(12), 2106-2115. https://doi.org/10.1377/hlthaff.2014.0914

Branco, M. S. S., \& Linhares, M. B. M. (2018). The toxic stress and its impact on development in the Shonkoff's Ecobiodevelopmental Theorical approach. Estudos de Psicologia (Campinas), 35(1), 89-98. https://doi.org/10.1590/1982-02752018000100009

Braveman, A. P. (2009). Health disparities beginning in childhood: A life-course perspective. Pediatrics, 124 . https://doi.org/10.1542

Caldwell, J. ., Shaver, P. ., Li, C., \& Minzenberg, M. . (2011). Childhood maltreatment, adult attachment and depression as predictors of parental self-efficacy in at-risk mothers. Journal Aggress Maltreat Trauma, 20, 595-616. https://doi.org/10.1080/10926771.2011.595763

Cohan, S. ., Jang, K. ., \& Stein, M. . (2006). Confirmatory factor analysis of a Short Form of the Coping Inventory for Stressful Situations. Journal of Clinical Psychology, 62.

Corrigan, P., McCorkle, B., Schell, B., \& Kidder, K. (2003). Religion and spirituality in the lives of people with serious mental illnes. Community Mental Health Journal, 39(6).

Crnic, K. ., Gaze, C., \& Hoffman, C. (2005). Cumulative parenting stress across the preschool period: relations to maternal parenting and child behavior at age 5. Infant and Child Development, $14,117-132$. https://doi.org/10.1002/icd.384

Daulay, N. (2018). Parenting Stress of Mothers in Children with Autism Spectrum Disorder: A Review of the Culture in Indonesia. KnE Social Sciences, 3(5), 453. https://doi.org/10.18502/kss.v3i5.2349

Davis, N. O., \& Carter, A. S. (2008). Parenting stress in mothers and fathers of toddlers with autism spectrum disorders: Associations with child characteristics Disorders. Journal of Autism Developmental, 38, 1278-1291.

Deater-deckard, K. (1998). Parenting Stress and Child Adjustment: Some Old Hypotheses and New Questions. Clinical Psychology Science and Practice, 5(3). 
Deckard, K. D.-, \& Scarr, S. (1996). Parenting stress among the dual-earner mothers and fathers: are there gender differences? Journal of Family Psychology, 10, 45-59. https://doi.org/10.1037/0893-3200.10.1.45

Dunham, S., \& Dermer, H. (2011). Poisonous Parenting : Toxic Relationships Between Parents And Their Adult. Routledge Taylor \& Francis Group.

Ekas, N., \& Whitman, T. L. (2010). Autism symptom topography and maternal socioemotional functioning. American Journal on Intellectual and Developmental Disabilities, 115(3), 234249.

Felitti, V. J., Anda, R. F., Nordenberg, D., Williamson, D. F., Spitz, A. M., Edwards, V., Koss, M. P., \& Marks, J. S. (1998). Household Dysfunction to Many of the Leading Causes of Death in Adults The Adverse Childhood Experiences ( ACE) Study. 14(4), 245-258.

Fitzgerald, M. ., Shipman, K. ., Jackson, J. ., McMahon, R. ., \& Hanley, H. . (2005). Perceptions of parenting versus parent-child interactions among incest survivors. Child Abuse Negl, 29, 661-681. https://doi.org/10.1016/j.chiabu.2004.10.012

Gottman, J. M., \& Silver, N. (1999). The seven principles for making marriage work. Three Rivers Press.

Juster, R. P., McEwen, B. S., \& Lupien, S. J. (2010). Allostatic load biomarkers of chronic stress and impact on health and cognition. Neuroscience and Biobehavioral Review, 35(1), 2-16. https://doi.org/10.1016

K., J., Margaret, M., \& Disiye, A. (2020). Toxic Parenting Adversely Correlates To Students' Academic Performance In Secondary Schools In Uasin Gishu County, Kenya. International Journal of Scientific and Research Publications (IJSRP), 10(7), 249-253. https://doi.org/10.29322/ijsrp.10.07.2020.p10331

Koeske, G. F., \& Koeske, R. D. (1990). The Buffering Effect Of Social Support On Parental Stress. American Journal of Orthopsychiatry, 60(3).

Kuczynski, L., \& Kochanska, G. (1990). Development of children's non-compliance strategies from toddlerhood to age 5. Developmental Psychology, 26, 8-408.

Lazarus, R. S. (1993). Coping theory and research: Past, present, and future. Psychosomatic Medicine, 55, 234-247.

Mash, E. J., \& Johnston, C. (1990). Determinants of parenting stress: Illustrations from families of hyperactive children and families of physically abused children. Journal of Clinical Child Psychology, 19, 313-328.

Mikulincer, M., Shaver, P. R., Bar-on, N., \& Ein-dor, T. (2010). The Pushes and Pulls of Close Relationships : Attachment Insecurities and Relational Ambivalence. PS Sozialpsychologie, 98(3), 450-468.

Mortensen, J. A., \& Barnet, M. A. (2020). The role of child care in supporting the emotion regulatory needs of maltreated infants and toddlers. The University of Arizona.

National Academies of Sciences, Engineering, and M. (2016). Parenting Matters: Supporting Parents of Children Ages 0-8. The National Academies Press. https://doi.org/doi:10.17226/21868

National Scientific Council on the Developing Child. (2007). Key concepts: toxic stress. National Scientific Council on the Developing Child.

Ostberg, M., \& Hagekull, B. (2000). A structural modeling approach to the understanding of parenting stress. Journal of Clinical Child Psychology, 29, 615-625.

Pediatrics, A. A. of. (2018). ACEs and toxic stress. American Academy of Pediatrics. 
Rodenburg, R., Meijer, A. M., Dekovic, M., \& Aldenkamp, A. (2007). Parents of children with enduring epilepsy: Predictors of parenting stress and parenting. Epilepsy \& Behavior, 11, 197-207.

Shonkoff, J. P., Garner, A. S., Siegel, B. S., Dobbins, M. I., Earls, M. F., McGuinn, L., \& Wood, D. L. (2012). The lifelong effects of early childhood adversity and toxic stress. Pediatrics, 129(1), 232-246. https://doi.org/10.1542

Shonkoff, J.P. (2012). Leveraging the biology of adversity to address the roots of disparities in health and development. Proceedings of the National Academy of Sciences of the United States of America, 109(SUPPL.2), 17302-17307. https://doi.org/10.1073/pnas.1121259109

Shonkoff, Jack P., \& Bales, S. N. (2011). Science Does Not Speak for Itself: Translating Child Development Research for the Public and Its Policymakers. Child Development, 82(1), 1732. https://doi.org/10.1111/j.1467-8624.2010.01538.x

Shonkoff, Jack P., \& Levitt, P. (2010). Neuroscience and the Future of Early Childhood Policy: Moving from Why to What and How. Neuron, 67(5), 689-691. https://doi.org/10.1016/j.neuron.2010.08.032

Shonkoff, Jack P. (2010). Building a New Biodevelopmental Framework to Guide the Future of Early Childhood Policy. 81(1), 357-367.

Shonkoff, Jack P, \& Fisher, P. A. (2013). Rethinking evidence-based practice and two-generation programs to create the future of early childhood policy. 25, 1635-1653. https://doi.org/10.1017/S0954579413000813

Shonkoff, Jack P, Richter, L., Gaag, J. Van Der, Bhutta, Z. A., Shonkoff, A. J. P., \& Richter, L. (2012). An Integrated Scienti fi c Framework for Child Survival and Early Childhood Development. Pediatrics. https://doi.org/10.1542/peds.2011-0366

Siegel, B. S., Dobbins, M. I., Earls, M. F., Garner, A. S., Pascoe, J., Wood, D. L., High, P. C., Donoghue, E., Fussell, J. J., Gleason, M. M., Jaudes, P. K., Jones, V. F., Rubin, D. M., Schulte, E. E., Macias, M. M., Bridgemohan, C., Goldson, E., McGuinn, L. J., Weitzman, C., \& Wegner, L. M. (2012). Early childhood adversity, toxic stress, and the role of the pediatrician: Translating developmental science into lifelong health. Pediatrics, 129(1). https://doi.org/10.1542/peds.2011-2662

Slopen, N., Mclaughlin, K. A., \& Shonkoff, J. P. (2014). Interventions to Improve Cortisol Regulation in Children : A Systematic Review abstract. https://doi.org/10.1542/peds.20131632 